Print ISSN: 2288-4637 / Online ISSN 2288-4645

doi:10.13106/jafeb.2020.vol7.no10.149

\title{
Place Brand Equity and Domestic Investors' Choice: A Case Study in Vietnam
}

\author{
Huong Thi Thu PHAM${ }^{1}$, Nga Thi PHAM²
}

Received: July 03, 2020 Revised: August 23, 2020 Accepted: August 28, 2020

\begin{abstract}
Selecting an investment location is one of the most crucial decisions of investors as it has a great influence on the operation and development of the business in the future. At the same time, the attraction of localities will bring advantages for socio-economic development for the localities invested. Investors are interested in localities that have the potential to invest. The study focused on analyzing and testing the influence of place brand equity on the choice of investment locations of domestic investors through a regression analysis using 425 survey samples of investors in Phu Tho province, one of the northern industrial zones in Vietnam. Research results showed that $56.5 \%$ of investment decisions depended on factors from place brands. In addition, in the decision-making process for choosing investment locations, brand awareness factor had the greatest impact on investor's decisions, followed by brand image and brand personality, and finally brand confidence had the smallest impact. Therefore, in the coming time, in order to retain and attract domestic investors to choose Phu Tho as an investment and business destination, it is necessary to increase the value of place brand equity and implement solutions to promote place brands to investors.
\end{abstract}

Keywords: Place Brand, Place Brand Equity, Domestic Investors, Phu Tho Province, Vietnam

JEL Classification Code: D01, D20, E22

\section{Introduction}

There have been several studies on attracting investments from the perspective of place marketing, in which research using place brands to attract investment revived interests from scholars. The theoretical point mentioned by a number of researchers was that the place brand had an influence on the investor's decision of the investment location selection (Pantzalis \& Rodriguez, 1999; Florida, 2002; Jansson \& Power, 2006 ; Kavaratzis, 2004; Jacobsen, 2009, 2012; Metaxas, 2010; Cleave et al., 2016); a number of scholars focused on the aspect of place brand equity and offered theoretical arguments that place brand equity influenced the investor's choice of an

${ }^{1}$ First Author and Corresponding Author. Lecturer, Faculty of Economics and Business Administration, Hung Vuong University, Phu Tho, Vietnam [Postal Address: Nong Trang Ward, Viet Tri City, Phu Tho Province, 35000, Vietnam]

Email: huongdhhv84@gmail.com

${ }^{2}$ Lecturer, Thai Nguyen University of Economics and Business Administration, Thai Nguyen, Vietnam.

Email: ptnga2020@tueba.edu.vn

(c) Copyright: The Author(s)

This is an Open Access article distributed under the terms of the Creative Commons Attribution Non-Commercial License (https://creativecommons.org/licenses/by-nc/4.0/) which permits unrestricted non-commercial use, distribution, and reproduction in any medium, provided the original work is properly cited. investment location (Jacobsen, 2009, 2012; Metaxas, 2010). Accordingly, the empirical research to test how place brand equity affects investor's decisions is still limited (Jacobsen, 2012). Most research has mainly focused on investment decisions of FDI investors (Nguyen, 2020; Nguyen, 2020; Tung \& Thang, 2020); moreover, most of these studies have been conducted in developed countries with advanced industry, where the largest foreign investment in the world is attracted. Therefore, there is a need to conduct a study in a developing country to test whether place brand equity influences domestic investors' choice of investment location or not.

In Vietnam, recent research on place brands, especially about the influence of place brands on investors' decision of investment site selection, has been limited. Previous studies were divided into two main directions: the first one confirmed that place brands are one of the factors influencing the decision of investors (Ho, 2011; On \& Khanh, 2015; Bang et al., 2016); the second one illustrated that the aspect of place brand attribute affects investors' satisfaction (Tho \& Trang, 2009; Tuan \& Long, 2013; Kien et al., 2014). These studies have summarized the models as well as found the variables that have a direct impact on investors' decisions and satisfactions. However, the first research group has only asserted that place brands influenced the decision of investors without mentioning other aspects of place brands. 
The second research direction has focused on the content of place brands with their attributes only, not yet on place brand equity. At the same time, this work group focused on assessing the effect of place brand attributes on investor satisfaction (i.e. the reaction of the investors that takes place after the investment decision). Moreover, the object of research of a number of studies focused on business investors in general, including both domestic and foreign investors; and a number of studies focused on foreign investors only; hence, there is almost no research focusing on domestic investors. In addition, these research results are not necessarily true for domestic investors. In terms of geography, the above studies were mainly conducted in the southern provinces in Vietnam (such as Tien Giang, Dong Nai, Nha Trang). In the north of Vietnam, apart from a study in Hai Duong province, other studies focused on assessing the place marketing situation through the tools of place marketing and assessing the business investment environment of the place in the viewpoint of investors, thus there is a lack of assessment of the influence of place brands on domestic investors' decision of selecting an investment location.

To fill this gap, the article aimed to enrich the theory of place brands by analyzing and testing the influence of place brand equity on the choice of domestic investors of investment location through regression analysis using the survey samples in Phu Tho province, in Vietnam. The results of this paper provide evidence for local policymakers to design solutions to increase the value of place brand equity and promote place brands to investors in order to retain and attract domestic investors to choose Phu Tho province of Vietnam as the investment and business destination.

\section{Literature Review}

\subsection{Place Brand}

Many researchers agreed that places could be branded like products and services (Kotler et al., 1999; Keller, 1998;
Hankinson, 2001). Rainisto (2003) introduced the concept: "Place brands are like corporate brands and can benefit the value of a place image". Brymer (2003) found that brands really have the power to change the world and the way of seeing the world and the approach to perceive a region, a territory and a country in a comparative relationship with others. Thus, in this view, place brands would help distinguish one locality from another. In the same opinion, Kavaratzis (2005) argued that locality was a branded entity if its own characteristics could help differentiate them from each other. In another research perspective, Zenker and Braun (2010, p. 3) introduced the concept: "Place Brand as a network of associations in the consumers' mind based on the visual, verbal, and behavioral expression of a place, which is embodied through the aims, communication, values, and the general culture of the place's stakeholders and the overall place design".

"Place brand assets express the perception of the place brand by the investor and they can be categorized into tangible and intangible place brand assets" (Jacobsen, 2009, p. 76). In other words, place brand assets are a collection of values associated with place names or logos, which would be added to local products to add value to investors, and this was also explained as the reason why investors chose that locality.

The place brand equity components are summarized and proposed in Table 1.

\subsection{Decision on Investment Location}

The choice of investment location is one of the business decisions that need to be made carefully. Previous research confirmed that investment locations were related to business success (Alli et al., 1991; Ghosh et al., 1995). According to Hayter (1997), the decision to select an investment location could be considered as part of strategic investment decisions, i.e., it was made to meet the basic motivation of the business strategy by accessing new markets or sources of supply in a way that was tailored to each company.

Table 1: Place brand equity components

\begin{tabular}{|l|l|l|}
\hline Category & Place brand Assets & \multicolumn{1}{c|}{ Source } \\
\hline \multirow{5}{*}{ Tangible } & Perceived quality & Jacobsen (2009); Jacobsen (2012); Bose et. al. (2016). \\
\cline { 2 - 3 } & Brand impression & Kavaratzis (2007); Dinne (2008); Jacobsen (2009); Jacobsen (2012). \\
\cline { 2 - 3 } & Brand image & $\begin{array}{l}\text { Risitano (2005); Dinne (2008); Jacobsen (2009); Zenker and Martin (2011); } \\
\text { Jacobsen (2012); Bose et. al. (2016). }\end{array}$ \\
\hline \multirow{3}{*}{ Intangible } & Brand awareness & $\begin{array}{l}\text { Risitano (2005); Kubacki and Skinner (2006); Dinne (2008); Jacobsen (2009); } \\
\text { Zenker (2011); Jacobsen (2012); Bose et. al. (2016); Chekalina et. al. (2016). }\end{array}$ \\
\cline { 2 - 3 } & Brand personality & $\begin{array}{l}\text { Risitano (2005); Jacobsen (2009); Baxter and Kerr (2010); Zenker (2011); } \\
\text { Jacobsen (2012). }\end{array}$ \\
\cline { 2 - 3 } & Brand confidence & Jacobsen (2009); Jacobsen (2012). \\
\hline
\end{tabular}


In the view of Ho (2011), the decision to select an investment location was the act of selecting a certain locality to carry out their investment activities. Investors would decide to invest in the locality where they felt comfortable, progressive as desired and possible to bring them a lot of benefits. Accordingly, they often tend to keep investing and doing their business in the locality for a long time and expanding their investment activities as well as introducing the locality to other investors.

\subsection{Relationship between Place Brands and Investment Location}

Place brands have become an integral part of local and regional economic development strategies in the global competition for business investment. Place brands are not only a good policy to attract and maintain business, but also a way to make the place be positioned more businessfriendly. A locality that builds a place brand will strongly increase its reputation. Attracting businesses to the locality contributes to improving the place economic base, thereby strengthening the place brand by increasing the number of the advertised assets, and in the meanwhile, creating a place reputation of positive investment. As the business grows in size, the locality will become more attractive to investors with a message as a good place to do business (Cleave et al., 2016).



According to Florida (2002) and Jansson and Power (2006), localities that have built strong brands will be easier to attract knowledge-industry companies. In addition, Pantzalis and Rodriguez (1999) also suggested that capital transfer is greatly influenced by place awareness as a brand, while Jansson and Power (2006) had evidence to demonstrate that place branding strategy plays an important role in the race to attract foreign investment.

In the same opinion, Jacobsen (2009) also proposed his viewpoint and established a theoretical model of the relationship between place brands and investment decisions. Accordingly, the behavior of local customers depended on the evaluation of place brands, or in another word, the investor's decision to invest in a locality was influenced by the place brand. This view was developed by Metaxas (2010) and was evidenced through an empirical research in Lucbeck (Germany), in which the decision to invest in creative industries was positively influenced by place brands (Jacobsen, 2012).

The theory and practice both affirmed that place brands are one of the most important factors influencing investors' decision to choose investment locations. Investors will look for the branded localities to invest in because it will help them save costs on understanding the investment environment and avoid risks (Ho, 2011). Therefore, place brands had a positive impact on investors' decisions (Bang et al., 2016). Place brands had a positive influence on promoting investors' decisions in the selection of investment locations.

Figure 1: Proposed research framework 


\section{Data and Methodology}

\subsection{Data}

\subsubsection{Empirical Framework}

Based on an overview of previous studies, especially Jacobsen's ones $(2009,2012)$, combined with the context of research in Vietnam, the authors proposed the following research model (see Figure 1):

\section{Measurement of variables}

Measurement of the independent variables (initial measurement 1) was inherited from the measurement by Jacobsen (2012) and then adjusted and developed through qualitative research. The measurement of decision on investment site selection was built on qualitative research using in-depth interviews. The observed variables were measured by the 5-point Likert scale, from 1 (totally disagree), 2 (disagree), 3 (neutral), 4 (agree) to 5 (totally agree).

\subsubsection{Descriptive Statistics}

Data was collected from the survey of 450 domestic investors in Phu Tho province, with 425 valid samples. The characteristics of the sample are described in Table 2 and Table 3 as follows:

\subsection{Methodology}

This section describes in detail the research instrument, sampling process and data collection techniques.

\subsubsection{Research Instrument}

The survey tool was a two-part questionnaire. The questionnaire was translated from English into Vietnamese by the reverse translation method. The questionnaire was designed with two parts, in which Part 1 had 12 questions including seven closed multiple-choice questions and five opened questions to collect basic information about the company such as company name, head office, establishment time, field and scope of business, etc. Part 2 included 24 statements (items) related to six components of place brand equity. These scales were inherited from previous studies and words have been changed to fit the research context. These statements were measured on a 5-point Likert scale, from strongly disagree to strongly agree. In particular, the scale of place brand personality, perceived quality, brand impression and brand image was adapted from Jacobsen (2012). The place brand awareness scale was referenced from Kaplanidou and Vogt (2003), Motameni and Shahrokhi (1998), Pappu and Quester (2006), Jacobsen (2012). The place brand confidence scale was referenced from the research of Martensen and Gronholdt (2004) and Jacobsen (2012). Meanwhile, the scale of investor's decision on choosing location was built by the authors through in-depth interviews and focus group discussion with place marketing experts and domestic investors. These scales were rated by previous studies as reliable.

The questionnaire was pre-tested on a sample of domestic investors of $40(n=40)$. During the pre-test, respondents were asked to give assessment of the clarity, comprehensiveness, and relevance of the words in the questionnaire. Minor adjustments have been made to the wording, presentation, and structure of the questionnaire in response to pre-test feedbacks and the opinions of five experts in the field of marketing and brand. Respondents during the trial would not participate in latter formal research.

\subsubsection{Sampling Procedure}

The study used Comrey and Lee's sampling rules (1992). With a sample size of 425 , it met the requirements of between good and very good sampling levels, even close to very good one. This sample size also satisfied the sampling principles of Trong and Ngoc (2008) and the sampling rules of Tabachnick and Fidell (2007). Respondents were the person who has the rights to make decisions on the choice of investment locations, such as the business owner, the chairman of the board of directors, the director, the deputy director, etc., of the selected enterprises.

Table 2: Descriptive statistics of research samples 1

\begin{tabular}{|l|c|c|c|c|c|c|}
\hline Variable name & N & Mean & Std. Deviation & Max & Min & Std. Error Mean \\
\hline Brand personality & 425 & 4.1506 & 0.56153 & 5 & 2.67 & 0.02724 \\
\hline Brand awareness & 425 & 3.9065 & 0.59050 & 5 & 2.5 & 0.0209 \\
\hline Perceived Quality & 425 & 3.8000 & 0.50619 & 5 & 2.4 & 0.02456 \\
\hline Brand impression & 425 & 4.1914 & 0.5899 & 5 & 3 & 0.02861 \\
\hline Brand confidence & 425 & 3.8276 & 0.55438 & 5 & 2 & 0.02689 \\
\hline Brand image & 425 & 4.4024 & 0.52181 & 5 & 3 & 0.02531 \\
\hline
\end{tabular}


Table 3: Descriptive statistics of research samples 2

\begin{tabular}{|c|c|c|c|}
\hline No. & Criteria & $\begin{array}{l}\text { Number of } \\
\text { responding sheet }\end{array}$ & Percentage (\%) \\
\hline \multirow[t]{4}{*}{1} & \multicolumn{3}{|l|}{ By types of enterprise } \\
\hline & Private enterprises & 116 & 27.3 \\
\hline & Limited liability companies & 166 & 39.1 \\
\hline & Joint stock companies & 143 & 33.6 \\
\hline 2 & \multicolumn{3}{|l|}{ By business size } \\
\hline \multirow[t]{7}{*}{2.1} & \multicolumn{3}{|l|}{ By labour size } \\
\hline & less than 10 employees & 167 & 39.3 \\
\hline & 10 to 50 employees & 190 & 44.7 \\
\hline & 51 to 100 employees & 28 & 6.6 \\
\hline & 101 to 200 employees & 15 & 3.5 \\
\hline & 201 to 300 employees & 13 & 3.1 \\
\hline & over 300 employees & 12 & 2.8 \\
\hline \multirow[t]{6}{*}{2.2} & \multicolumn{3}{|l|}{ By business capital sizes (unit: VND) } \\
\hline & under 10 billion & 203 & 47.8 \\
\hline & 10 to 20 billion & 130 & 30.6 \\
\hline & 21 to 50 billion & 49 & 11.5 \\
\hline & 51 to 100 billion & 17 & 4.0 \\
\hline & over 100 billion & 26 & 6.1 \\
\hline \multirow[t]{5}{*}{3} & \multicolumn{3}{|l|}{ By investment/operation time } \\
\hline & 1 to 5 years & 66 & 15.5 \\
\hline & 6 to 10 years & 215 & 50.6 \\
\hline & 11 to 15 years & 108 & 25.4 \\
\hline & over 15 years & 36 & 8.5 \\
\hline \multirow[t]{12}{*}{4} & \multicolumn{3}{|l|}{ By sector } \\
\hline & Processing and manufacturing & 140 & 32.9 \\
\hline & Agriculture. forestry and fisheries & 32 & 7.5 \\
\hline & Construction and infrastructure & 61 & 14.4 \\
\hline & Mining & 19 & 4.5 \\
\hline & Warehousing. transportation and forwarding services & 25 & 5.9 \\
\hline & Accommodation and food services & 13 & 3.0 \\
\hline & Education and training & 3 & 0.7 \\
\hline & Healthcare and medical industry & 6 & 1.4 \\
\hline & Trade and wholesale. retail & 110 & 25.9 \\
\hline & Other sectors & 16 & 3.8 \\
\hline & Total & 425 & 100 \\
\hline
\end{tabular}


To select the research sample, the authors used a nonprobability sampling method, in combination with the quota sampling and convenient sampling techniques. Using this method was appropriate because it would save time and cost and avoid the situation affecting the sampling process, for example, the selected companies in the sample stopped working, relocated, changed their operation fields, or were located in hard-to-reach locations. At the same time, this approach also helped to actively select respondents with goodwill and being ready to answer the questionnaire. Based on the list of enterprises provided by the Department of Planning and Investment of Phu Tho province, using the quota sampling method, the study divided the overall research sample into groups, by locality and by business field. First, the whole sample was divided into groups by locality, in which each locality was a group. Then, in each group, it was combined with the field-based sampling rate to calculate the quota for each area. Finally, the research conducted convenience non-random sampling for survey questionnaire.

\subsubsection{Data Collection}

The data was collected via two forms-direct interviews and mails/emails to domestic businesses operating in Phu Tho province. For businesses with close geographical area and easy access to, the authors conducted direct interviews. Thereby, the researchers could explain more clearly the objectives and survey questions, and the response rate was higher and the interviewer's could on-the-spot check and verify the data. This also helped control the respondents in terms of minimizing the cases of irrelevant respondents. For businesses where it was difficult to meet the targeted respondents directly and the geographical area was too far, the authors contacted in advance and sent the questionnaire to the surveyed respondents by post mail attached to the envelope that addressed the recipient. After sending the questionnaire by mail, the authors would send the link to the online survey questionnaire on google docs via email to make it easier for the surveyed respondents to answer as well as to achieve high response rates.

\section{Results and Discussion}

\subsection{Reliability of Scales and Exploratory Factor Analysis (EFA)}

\subsubsection{Assessment of the Reliability of the Scales}

The results of the analysis of the scale reliability showed that the Cronbach's Alpha was greater 0.7 and Corrected item - total correlation was greater than 0.3. Therefore, all observed variables obtained reliable values for factor analysis.

The EFA analysis results showed that 23 observations representing six groups of scales were grouped into five factors. The observed variables of the brand personality and brand impression scales converged in one factor. From

Table 4: Results of the assessment of the scale reliability and Exploratory Factor Analysis

\begin{tabular}{|c|c|c|c|c|}
\hline Observed Variables & Cronbach's Alpha & $\begin{array}{c}\text { Min_Corrected } \\
\text { Item-Total } \\
\text { Correlation }\end{array}$ & KMO & $\begin{array}{l}\text { TVE } \\
(\%)\end{array}$ \\
\hline $\begin{array}{l}\text { Brand personality } \\
\text { (TC1,TC2, TC3) }\end{array}$ & 0.915 & 0.758 & \multirow{7}{*}{.927} & \multirow{7}{*}{72.51} \\
\hline $\begin{array}{l}\text { Brand awareness } \\
\text { (NB1, NB2, NB3, NB4) }\end{array}$ & 0.82 & 0.629 & & \\
\hline $\begin{array}{l}\text { Perceived Quality } \\
\text { (CL1, CL2, CL3, CL4,CL5) }\end{array}$ & 0.853 & 0.566 & & \\
\hline $\begin{array}{l}\text { Brand impression } \\
\text { (AT1, AT2, AT3) }\end{array}$ & 0.915 & 0.795 & & \\
\hline $\begin{array}{l}\text { Brand confidence } \\
\text { (NT1, NT2, NT3, NT4) }\end{array}$ & 0.897 & 0.681 & & \\
\hline $\begin{array}{l}\text { Brand image } \\
(\mathrm{HA} 1, \mathrm{HA} 2, \mathrm{HA} 3, \mathrm{HA} 4, \mathrm{HA} 5)\end{array}$ & 0.908 & 0.761 & & \\
\hline $\begin{array}{l}\text { Decision on investment location } \\
\text { (QD1, QD2, QD3, QD4) }\end{array}$ & 0.881 & 0.65 & & \\
\hline
\end{tabular}


both theoretical and practical points of view, the correlation between these two factors was quite high. Place brand personality is an internal characteristic of the locality associated with place characteristics that are perceived by local customers. At the same time, place brand personality enhances the place differences, thus helping to distinguish localities from each other (Hankinson \& Cowking, 1993; Usakli \& Baloglu, 2011). Therefore, the observed variables measuring of place brand impression referenced from the study of Jacobsen (2012), including geographical location, natural resources, infrastructure, were all differentiation factors of the place and helped distinguish localities from each other. It was from these factors that helped investors know whether the locality is suitable, attractive ora good investment location for their business activities. Therefore, in the context of Vietnam, investors believed that the observed variables all described the same concept. Therefore, the authors combined the two variables of brand personality and brand impression into a new factor called local brand personality with six observed items. The remaining observed variables were all loaded into an independent factor. All observed variables were recoded and included in the further analysis steps.

\subsection{Testing Hypotheses}

\subsubsection{Testing Research Hypotheses}

To test the hypotheses, the regression analysis was used. The result shows that Brand personality, Brand awareness, Brand confidence, and Brand Image have a positive impact on investors' decision (Beta $>0$ and p-value $<0.05$ ). Besides, the Perceived quality has not impact on investors' decision.

Table 5: The results of regression analysis between place brand equity and domestic investor's choice of location

\begin{tabular}{|c|c|}
\hline Variable $\begin{array}{r}\text { Dependent variable: Domestic } \\
\text { investors' decision on } \\
\text { investment } \\
\text { location }\end{array}$ & Beta \\
\hline \multicolumn{2}{|l|}{ Independent variable } \\
\hline Brand personality & $0.171^{\text {***}}$ \\
\hline Brand awareness & $0.289^{* * *}$ \\
\hline Perceived quality & -0.019 \\
\hline Brand confidence & $0.111^{* *}$ \\
\hline Brand Image & $0.218^{* * *}$ \\
\hline Adjusted R2 & 0.565 \\
\hline $\mathrm{F}$ & $53.786^{* * *}$ \\
\hline \multicolumn{2}{|c|}{$N=425 ;{ }^{* *}:$ Sig $\leq 0.01 ;{ }^{* *}:$ Sig $\leq 0.05 ;^{*}:$ Sig $\leq 0.1$} \\
\hline All $\beta$ coefficients have been standardized. & \\
\hline
\end{tabular}

The relationship between dependent variable and independent variables was expressed as a standardized regression equation as follows:

$$
\mathrm{QD}=0.171 \mathrm{TC}+0.289 \mathrm{NB}+0.111 \mathrm{NT}+0.218 \mathrm{HA}
$$

The study demonstrated that there were four components of place brands influencing domestic investors' decision to select investment locations, namely, brand awareness, brand image, brand personality, and brand confidence. In particular, place brand awareness had the strongest influence on the domestic investor's decision to select the investment location $(\beta=0.289)$, followed by brand image $(\beta=0.218)$, then brand personality $(\beta=0.171)$, and finally brand confidence had the smallest impact $(\beta=0.1111)$. These results are objective and appropriate to the context of Vietnam. Following the threecomponent attitude model, a person's attitude includes: recognition, appreciation or enjoyment, and behavioral intention. Accordingly, based on collected information and personal experience, customers have an understanding and awareness of the product. From product awareness, customers have an appreciation and interest in the product, which is the basis for customer behavior. Therefore, when investors have a high level of brand awareness about a locality, they will tend to choose investment in that locality. When the locality is an appropriate investment destination, and attractive and good enough for businesses then the decision to select the investment location of investors will be high.

The results of the study confirmed that there was a positive relationship between the place brand image and the choice of investment locations of domestic investors with the significance level of $95 \%$. This result was consistent with the research results of Jacobsen (2012), Metaxas (2010) and also consistent with the view of place marketing, i.e., a province with a positive image would bring about place competitive advantage which would lead investors to decide to select the investment location. The reality of place branding in some provinces and cities in Vietnam has been clearly shown that the use of place brand image to attract investment capital could pave the way for place's economic development such as Da Nang city, Quang Ninh province, Dong Thap province.

The results of the study showed that there was a positive relationship between the brand personality and the decision to choose investment locations of domestic investors are at the $95 \%$ significance level. This result was consistent with the research results of Jacobsen (2012). Today, in the race to attract investment capital, every locality improves its investment environment, promotes investment and offers preferential policies for investors. From the investors' point of view, localities can create the above factors and improve them over time, however, geographical location and natural resources are naturally gifted conditions that localities cannot create. In addition, there are localities with 
high quality infrastructure, many preferential policies, but not necessarily suitable for investors in terms of objectives, investment fields, target markets, and resources. Therefore, investors will consider this factor carefully to make decisions on whether to select localities as investment locations or not.

The research results have proved that there was a positive relationship between place brand confidence and decisions of the choice of investment location of domestic investors. This result was consistent with the theoretical overview of place brand assets. Brand personality will create confidence in place brands. Confidence is a kind of social capital, which can create as much as financial capital, human capital or infrastructure capital. When people have trust, it will motivate action. When investors have confidence in the local government, they will choose that locality as a business investment location.

The research results also confirmed that the perceived quality did not affect the decision on investment location selection of domestic investors. This result contradicted Jacobsen's (2012). There was such inconsistency due to differences in surveyed respondents and research contexts. The behavior of foreign investors is different from that of domestic ones, especially in the formality of the selection process and means of project mobilization. In the process of selecting an investment location, foreign investors are often influenced by the national effects, that is, the priority is usually given to selecting localities where their country's companies are present and they strictly adhere to stages of the investment site selection process. At the same time, the importance of the factors influencing foreign investors' decision to select investment locations is also different from that of domestic ones. For domestic investors in Vietnam, perceived quality factors are considered as an obvious condition that localities need to improve to attract investment; this also reflects that, over time, the locality has gradually improved and met the requirements of public administrative services and professional working methods.

\subsubsection{Comparing the Effects of Groups in Each Control Variable on the Domestic Investor's Choice of Location}

To test the difference between a domestic investor's decision to select an investment location based on the above controlling variables, the authors used ANOVA variance analysis method with significance level smaller than 0.05 $(<0.05)$.

Levene test results for different types of enterprises and the decision to select the investment location, with p-value $=0.960>0.05$, showed that the homogeneity of variance condition was satisfied, i.e., there was no difference in variance between the two groups. Thus, ANOVA analysis results could be used. ANOVA analysis showed that the $\mathrm{p}$-value $=0.000<0.05$, which indicated that there was a significant difference in the decision to select investment locations among types of enterprise. According to the tables in Appendix, the average value of decision on investment location of the group of joint stock companies was the highest (4.5787), followed by the limited liability companies (4.3253) and finally by private enterprises (4.2953). This was also shown more clearly through the results of Posthoc ANOVA analysis, which indicated that there was a significant difference in the choice of investment locations of domestic investors between private enterprises and jointstock companies, between limited liability companies. Term and joint-stock ones. In particular, the difference between private enterprises and joint stock companies was larger (due to the average difference of 0.284 ), the difference between limited liability companies and joint stock ones was smaller (due to the average difference of 0.25337 ). There was no difference between private enterprises and limited liability companies.

Levene's testing results showed that the p-value of both capital size and labor groups in the relation with the decision to select an investment location were $0.000<0.05$; that of investment sectors and the decision to select an investment location were $0.007<0.1$. Thus, it could be affirmed that there was a difference in variance among groups by capital size, by labor and by sector. Since it did not satisfy the assumption of the one way ANOVA test, ANOVA analysis could not be used.

Levene test results for operation time group and the decision to select an investment location with $\mathrm{p}$-value $=$ $0.423>0.05$ showed that the homogeneity of variance condition was satisfied, there was no difference in variance between the two groups. Thus, ANOVA analysis results could be used. ANOVA analysis showed that the p-value $=$ $0.000<0.05$, which indicated that there was a difference in the choice of investment location among different groups over operation time. According to the tables in Appendix, the average value of decision on investment location of the group of enterprises operating over 15 years was the highest (4.5903), followed by the group with an operating period of 11 to 15 years (4.5116), then the group of 6 to 10 years (4.3651) and finally the group of 5 years or less (4.2424). This was also shown more clearly through the results of Post-hoc ANOVA analysis, which indicated that there was a significant difference in the choice of investment locations of domestic investors among groups by time of operation, sorted descending in level of differences follows: (i) the average difference between enterprise group operating in the period of 1-to-5 years and that of over 15 years was 0.34785 ; (ii) the average difference between enterprise group operating in the period of 1-to-5 years and that of 11-to-15 years was 0.22615 ; (iii) the average difference between enterprise group operating in the period of 6-to-10 
years and that of over 15 years was 0.22516 ; (iv) the average difference between enterprise group operating in the period of 6-to-10 years and that of 11-to-15 years was 0.14646 .

\section{Conclusions and Implications}

\subsection{Conclusions}

Place brands are one of the contemporary issues that are studied and applied by many scholars and localities in different angles. Although there have been some empirical studies explaining the relationship between factors that influence investor decisions and aspects of place brand attributes that affect investor satisfaction, the previous studies mainly focused on FDI investors but ignored domestic investors. Accordingly, the aspect of place brand equity affecting the decision on the location of domestic investors has not been focused on research. Therefore, for the first time, in order to fill this gap and enrich the literature, this paper examined the relationship between place brands and domestic investor's decision to select investment locations by using regression analysis with the support of SPSS 20.0 software. The main results of the study from the data analysis of 425 investors in Phu Tho province included, first, the decision on the choice of investment location of domestic investors, which was influenced by four components of place brand equity: brand personality, brand awareness, brand confidence, and brand image. Secondly, there was a significant difference in a domestic investor's decision on the choice of investment location by types of enterprises and durations of operation/ investment. Therefore, the research indicated that, in order to attract investors to Phu Tho province, the province needs solutions to promote the brand and increase the place brand value. Future research may consider to expand the scope of the study to all of localities to assess the differences between localities and to compare the differences in the decision to select investment locations of native investors and investors from other localities.

\subsection{Implications}

Attracting investors to choose localities as investment and business destination is particularly significant for the development of a locality. To do that, the authors propose a number of recommendations to expand the brand and increase the place brand value of Phu Tho province in order to improve loyalty, retain existing investors and attract new investors.

Firstly, it is important to establish a program to promote investment potentials for encouraging investors to participate in and provide investors with reliable information sources. Besides, it is necessary to attract investors with strong trademarks to invest and do business in the province. This will create a positive effect as well as create traction to help Phu Tho pull and attract investors to invest in the province. One point to be noted down is that the province needs to determine the brand awareness of different investors to have specific solutions for each target in order to create awareness and enhance the level of awareness or maintain awareness level.

Secondly, it is necessary to develop a positioning strategy to highlight the place combining factors that make the province unique and different from other competing localities. In order to do so, localities need to carefully analyze the reasons why investors choose the localities as investment destination through the specific benefits they are looking for. Based on that, the locality could establish place brand image associated with the benefits and added value for investors.

Thirdly, in order to increase the place brand personality, it is recommended to invest more in infrastructure construction, planning rational exploitation of natural resources and taking the geographical advantage of the province, perfecting the investment and business environment for Phu Tho to become an attractive investment destination for investors. In parallel, the province needs to emphasize the place uniqueness and the ability to meet the needs of the targeted investors.

Fourthly, in order to strengthen and increase the confidence of investors, it is suggested to raise the sense of responsibility in the timely and effective implementation of guidelines, policies and comprehensive solutions of the Government and the province; actively support businesses to overcome difficulties and stabilize production; provide public services exactly as announced/committed to investors. Moreover, in order to strengthen business engagement with the government, the government needs to provide investor care and relationship management services.

\section{References}

Alli, K. L., Ramirez, G. G., \& Yung, K. (1991). Corporate headquarters relocation: evidence from the capital markets. Journal of the American Real Estate and Urban Economics Association, 19(4), 583-599.

Bang, N. V., Nghi, L. Q., \& Vi, L. C. (2016). Factors affecting FDI attraction inindustrial zones in Dong Nai. Science and Technology Development Journal, 19(2), 5-18.

Baxter, J., \& Kerr, G. (2010). The meaning and measurement of place identity and place image. In: The $50^{\text {th }}$ European regional science association congress (pp. 19-23).

Bose, S., Roy, S. K., \& Tiwari, A. K. (2016). Measuring customerbased place brand equity (CBPBE): an investment attractiveness perspective. Journal of Strategic Marketing, 1(1), 17-32.

Brymer, C. (2003). Branding a country. Retrieved July 20, 2020, from: http://www.cuts-citee.org/CDS02/pdf/CDS02Session3-02.pdf. 
Chekalina, T., Fuchs, M., \& Lexhagen, M. (2016). Customer-Based destination brand equity modeling: The role of destination resources, value for Money, and value in use. Journal of Travel Research, 57(1), 31-51.

Cleave, E., Arku, G., Sadler, R., \& Gilliland, J. (2016). The role of place branding in local and regional economic development: bridging the gap between policy and practicalit. Regional Studies, Regional Science, 3(1), 207-228. https://doi.org/10.10 $80 / 21681376.2016 .1163506$

Comrey, A. \& Lee, H. (1992). A first course in factor analysis. Hillsdale, MI: Erlbaum.

Dinnie, K. (2008). Nation Branding-Concepts, Issues, Practice. Oxford, UK: Butterworth-Heinemann.

Florida, R. (2002). The rise of the creative class and how it's transforming work, Leisure, community and everyday life. New York, NY: Basic Books.

Ghosh, C., Rodriguez, M., \& Sirmans, C. F. (1995), Gains from corporate headquarters relocations: evidence from the stock market, Journal of Urban Economics, 38, 291-311.

Hankinson, G. (2001), Location branding: a study of twelve English cities, Journal of Brand Management, 9(2), 127-142.

Hankinson, G., \& Cowking, P. (1993). Branding in Action. London, UK: McGraw-Hill.

Hayter, R. (1997). The Dynamics of Industrial Location-The Factory, the firm and the Production System. Chichester, UK: John Wiley \& Sons.

Ho, D. P. (2011). Factors affecting investment attraction in industrial zones. In: Quantitative research methods and practical studies in development economics - agriculture (pp. 67-91). Hanoi, Vietnam: Phuong Dong Publishing House.

Jacobsen, B. (2009). Investor-based place brand equity: a theoretical framework, Journal of Place Management and Development, 2(1), 70-84.

Jacobsen, B. (2012). Place brand equity: a model for establishing the effectiveness of place brands, Journal of Place Management and Development, 5(3), 253-271.

Jansson, J., \& Power, D. (2006). The image of the city: Urban branding as constructed capabilities in Nordic city Regions. Copenhagen, Denmark: Nordic Council of Ministers.

Kavaratzis, M. (2004). From City Marketing to City Branding: An Interdisciplinary Analysis with Reference to Amsterdam, Budapest and Athens. PhD Thesis, University of Groningen, The Netherlands. Available at: http://dissertations.ub.rug.nl/ faculties/rw/2008/m.kavaratzis/

Kavaratzis, M. (2005). Place branding: a review of trends and conceptual models. The Marketing Review, 5(4), 329-42.

Kavaratzis, M. (2007). City marketing: the past, the present and some unresolved issues. Geography Compass, 1(3), 95-712.

Keller, K. L. (1998). Strategic Brand Management: Building, Measuring and Managing Brand Equity. Upper Saddle River, NJ: Prentice Hall.
Kien, D. T., Toan, T. M., Tuyen, B. Q., Duy, N. V., \& Lien, T. N. (2014). The impacts of local properties on investor's satisfaction: Evidence from Hai Duong, Vietnam. Journal of Economics and Development, 210(1), 43-52.

Kotler, P., Asplund, C., Rein, I., \& Haider, D. H. (1999). Marketing Places Europe: How to Attract Investments, Industries, Residents and Visitors to European Cities, Communities, Regions and Nations. London, UK: Pearson Education Ltd.

Kubacki, K., \& Skinner, H. (2006). Poland: exploring the relationship between national brand and national culture. Journal of Brand Management, 13(4/5), 284-299.

Metaxas, T. (2010). Place marketing, place branding and foreign direct investments: Defining their relationship in the frame of local economic development process. Place Branding and Public Diplomacy, 6(3), 228-243.

Nguyen, H. H. (2020). Impact of Foreign Direct Investment and International Trade on Economic Growth: Empirical Study in Vietnam. Journal of Asian Finance, Economics, and Business, 7(3), 323-331. https://doi.org/10.13106/jafeb.2020.vol7.no3.323

Nguyen, V. T. (2020). The Role of Foreign Direct Investment and Trade on Environmental Quality in Vietnam. Journal of Asian Finance, Economics, and Business, 7(3), 289-294. https://doi. org/10.13106/jafeb.2020.vol7.no3.289

On, P. V., \& Khanh, T. P. D. (2015). Factors affecting investment attraction in industrial parks and industrial complexes in Tien Giang province.Economics \& Forecasting Journal, 9, 23-25.

Pantzalis, J., \& Rodriguez, C. A. (1999). Country names of brands: symbolic meaning and capital flows. Retrieved December 12, 2019, from: www.sba.muohio.edu/abas/1999/pantzajo.pdf.

Rainisto, S. K. (2003). Success factors of place marketing: A study of place marketing practices in Northern Europe and the United States. Doctoral Dissertation, Helsinki University of Technology, Institute of Strategy and International Business.

Risitano, M. (2005). The role of destination branding in the tourism stakeholders system: The Campi Flegrei Case. Faculty of Economics - University of Naples Federico II, Via Cinthia Campus of Monte S. Angelo, Naples, Italy.

Tabachnick, B. G., \& Fidell, L. S. (2007). Using multivariate statistics $\left(5^{\text {th }}\right.$ Ed. $)$. Upper Saddle River, NJ: Pearson Publishing.

Tho, L. D., \& Trang, N. T. M. (2009). Locality and Business Satisfaction, Scientific Research in Business Administration (pp. 73-145). Hanoi, Vietnam: Statistical Publishing House.

Tung, L. T., \& Thang, P. N. (2020). Impact of FDI on Private Investment in the Asian and African Developing Countries: A Panel-Data Approach. Journal of Asian Finance, Economics, and Business, 7(3), 295-302. https://doi.org/10.13106/ jafeb.2020.vol7.no3.295

Trong, H., \& Ngoc, C.N.M. (2008). Analyzing research data with SPSS. Hanoi, Vietnam: Hong Duc Publisher.

Tuan, N. A., \& Long, L. K. (2013). The influence of local attributes on the satisfaction of tourism businesses in Nha Trang. Journal of Economic Development, 271, 36-50. 
Usakli, A., \& Baloglu, S. (2011). Brand personality of tourist destination; An application of selfcongruity theory. Tourism Management, 32, 114-127.

Zenker, S., \& Braun, E. (2010). The place brand centre - A conceptual approach for the brand management of places. In: $39^{\text {th }}$ European Marketing Academy Conference. Copenhagen, Denmark.
Zenker, S., \& Martin, N. (2011). Measuring success in place marketing and branding. Place Branding and Public Diplomacy, 7(1), 32-41.

Zenker, S. (2011). How to catch a city? The concept and measurement of place brands. Journal of Place Management and Development, 4(1), 40-52. 